\title{
Molecular and morphological data from Thoosidae in favour of the creation of a new suborder of Tetractinellida
}

JosÉ Luis Carballo, Eric Bautista-Guerrero, Paco CÁrdenas, Jose Antonio CruzBarraza \& Jose Maria Aguilar-Camacho

To cite this article: JosÉ Luis Carballo, Eric Bautista-Guerrero, Paco CÁrdenas, Jose Antonio Cruz-Barraza \& Jose Maria Aguilar-Camacho (2018) Molecular and morphological data from Thoosidae in favour of the creation of a new suborder of Tetractinellida, Systematics and Biodiversity, 16:5, 512-521, DOI: 10.1080/14772000.2018.1457100

To link to this article: https://doi.org/10.1080/14772000.2018.1457100

\section{曲 Published online: 11 May 2018.}

Submit your article to this journal $\widetilde{ }$

Llll Article views: 224

Q View related articles 5

View Crossmark data $₫$

Citing articles: 3 View citing articles ¿ 


\title{
Molecular and morphological data from Thoosidae in favour of the creation of a new suborder of Tetractinellida
}

\author{
JOSÉ LUIS CARBALLO ${ }^{1}$, ERIC BAUTISTA-GUERRERO ${ }^{2}$, PACO CÁRDENAS ${ }^{3}$, \\ JOSE ANTONIO CRUZ-BARRAZA ${ }^{1} \&$ JOSE MARIA AGUILAR-CAMACHO ${ }^{4}$ \\ ${ }^{1}$ Instituto de Ciencias del Mar y Limnología, Universidad Nacional Autónoma de México (Unidad Académica Mazatlán), \\ Avenida Joel Montes Camarena s/n, Mazatlán (SIN) 82000, PO Box 811, México \\ ${ }^{2}$ Laboratorio de Ecología Marina, Centro de Investigaciones Costeras, Centro Universitario de la Costa, Universidad de Guadalajara, \\ Av. Universidad No. 2013 Del, Ixtapa, Puerto Vallarta, Jalisco, CP 48280, México \\ ${ }^{3}$ Division of Pharmacognosy, Department of Medicinal Chemistry, BioMedical Center, Husargatan 3, Uppsala University, Uppsala, \\ 75123 , Sweden \\ ${ }^{4}$ Zoology, Ryan Institute, School of Natural, Sciences, National University of Ireland Galway, University Road, Galway, Ireland
}

(Received 20 July 2017; accepted 7 March 2018)

\begin{abstract}
The Thoosidae (Porifera, Demospongiae, Tetractinellida) currently includes the genera Thoosa, Alectona, and Delectona. To this date, molecular data are only available for Alectona. In this study, the phylogenetic affinities of the genera Thoosa and Alectona have been investigated with the species T. mismalolli, T. calpulli, and T. purpurea from the Mexican Pacific using morphology and three molecular loci: the mitochondrial cytochrome oxidase subunit 1 (CO1 mtDNA), 28S rRNA (fragment D2), and 18S rRNA. Morphology and embryology showed that these genera are quite different from the rest of the tetractinellids because larvae of Alectona and Thoosa have unique features in sponges, such as the presence of monaxonic discs in Thoosa and tetraxonic discs in Alectona which disappear in the adult stages. A phylogenetic analysis using selected species from the order Tetractinellida revealed that Thoosa groups with Alectona thus confirming morphological studies. The peculiarities in spiculation and embryology of the Thoosa and Alectona larvae, which are markedly different from species belonging to the suborders Astrophorina and Spirophorina and their distant phylogenetic position (based on three molecular loci), suggest that Thoosidae could be placed in the new suborder Thoosina.
\end{abstract}

Key words: Astrophorina, molecular markers, Porifera, systematics, synapomorphy, Thoosidae

\section{Introduction}

The combination of molecular phylogeny with the traditional morphological characters in sponge systematics has showed incongruence in some orders and families (Morrow \& Cárdenas, 2015; Morrow et al., 2013; Redmond et al., 2011), which has led to major changes in the higher classification of the Demospongiae; the class with the greatest number of species (Van Soest et al., 2012). The current classification divides Demospongiae into three subclasses: Verongimorpha, Keratosa, and Heteroscleromorpha with 22 orders, some of them recently created, or resurrected, such as the order Tetractinellida, divided into two suborders: Astrophorina and Spirophorina. The species of this order possess monactine

Correspondence to: J. L. Carballo. E-mail: jlcarballo@ola.icmyl. unam.mx megascleres and triaenes in various shapes; microscleres include sigmaspires, asters, microrhabds, microxeas, or raphides (Morrow \& Cárdenas, 2015).

The monophyly of Tetractinellida is clearly supported by morphological and molecular data (Borchiellini, Alivon, \& Vacelet, 2004; Chombard, Boury-Esnault, \& Tillier, 1998; Erpenbeck et al., 2007; Kelly \& Cárdenas, 2016; Lavrov, Wang, \& Kelly, 2008; Nichols, 2005). However, the first comprehensive molecular phylogenetic study of the suborder Astrophorina showed that some families and genera are polyphyletic (Cárdenas, Xavier, Reveillaud, Schander, \& Rapp, 2011). One of those polyphyletic families is Alectonidae Rosell, 1996 with a particularly unstable taxonomic history due to its boring habitus, spicule morphology, and larval features. Alectona was first classified in the family Clionaidae d'Orbigny, 1851 (order Hadromerida) (Rützler \& Stone, 1986), and 
later it was moved to the new family Alectonidae with the genera Thoosa Hancock, 1849 and Delectona de Laubenfels, 1936, as a part of the order Hadromerida (Rosell, 1996).

Vacelet (1999) suggested moving Alectona Carter, 1879 to Astrophorida because of the morphology of the spicules in the larvae (tetraxonic discs and amphiasters) which are similar to some astrophorid species. Nevertheless, Rützler (2002a) included this genus with other boring sponges such as Dotona Carter, 1880, Spiroxya Topsent, 1896, Neamphius de Laubenfels, 1953, Scolopes Sollas, 1888 and Delectona de Laubenfels, 1936, in the family Alectonidae while Thoosa remained in the family Clionaidae (Rützler, 2002b).

Borchiellini et al. (2004) by using a fragment of the $28 \mathrm{~S}$ rRNA confirmed that Alectona millari Carter, 1879 (type species of the genus) was more closely related to astrophorids than to hadromerids. Cárdenas et al. (2011) reached the same conclusion by using the CO1 mtDNA; although the sequence of $A$. millari did not cluster within any of the astrophorid clades. Interestingly, the sequence diverged between the major clades of Astrophorina and Spirophorina which seems to suggest a pivotal evolutionary step between the two suborders. However, the sequence of Neamphius huxleyi (Sollas, 1888), (with amphiasters but no triaenes), grouped more closely to desma-bearing astrophorids (Cárdenas et al., 2011). Thus, the family Thoosidae Cockerell, 1925 was resurrected (non Alectonidae because Thoosa was described before Alectona) to include Thoosa, Alectona, Delectona but not Neamphius de Laubenfels, 1953, considered as incertae sedis (Cárdenas \& Rapp, 2012).

In summary, different authors suggested the reallocation of Thoosa and Delectona along with Alectona in Thoosidae, because they share important morphological and biological features. They are excavating, and at least Thoosa and Alectona produce an unusual hoplitomella larva, which has particular spicules that are different from those observed in adult stages (BautistaGuerrero, Carballo, Aguilar-Camacho, \& SifuentesRomero, 2016; Topsent, 1920; Vacelet, 1999). Another interesting character shared by Thoosa and Alectona is the pit pattern made during the process of bioerosion, different to those produced by other boring sponges (Borchiellini et al., 2004; Calcinai, Bavestrello, \& Cerrano, 2004).

However, despite the morphological, cytological, and especially embryological evidence that suggest the grouping of Alectona with Thoosa, and their uniqueness amongst the Tetractinellida, we are still missing molecular data from Thoosa species to support this recommendation. In the Mexican Pacific, three Thoosa species have been described (Carballo, Cruz-Barraza, \& Gómez, 2004; Cruz-Barraza, Carballo, Bautista-Guerrero, \& Nava, 2011), and the reproductive cycle is known for one of them (Bautista-Guerrero, Carballo, \& Maldonado, 2010). The aim of this work was to assess the systematic position of species belonging to the genus Thoosa using three independent loci: CO1 mtDNA, 28S rRNA (D2), and 18S rRNA. Our results confirm that Thoosa and Alectona are closely related in the family Thoosidae. On the basis of morphological and molecular differences with suborders Astrophorina and Spirophorina, we propose the creation of the new suborder Thoosina.

\section{Materials and methods}

Specimens of Thoosa mismalolli Carballo, Cruz-Barraza \& Gómez, 2004 and T. calpulli Carballo, Cruz-Barraza \& Gómez, 2004 were collected by scuba diving in a shallow (5-9 $\mathrm{m}$ depth) coral community surrounding Isabel Island, Mexico $\left(21^{\circ} 52^{\prime} 30^{\prime \prime} \mathrm{N}, 105^{\circ} 54^{\prime} 54^{\prime \prime} \mathrm{W}\right)$. Specimens of T. purpurea Cruz-Barraza, Carballo, Bautista-Guerrero \& Nava, 2011 were collected from Islas Revillagigedo $\left(19^{\circ} 34^{\prime} 57^{\prime \prime} \mathrm{N}, 111^{\circ} 03^{\prime} 57^{\prime \prime} \mathrm{W}\right)$ also by scuba diving at 5-7 $\mathrm{m}$ depth. Specimens were deposited in 'Colección de Esponjas del Pacífico' (LEB-ICML-UNAM) (Table 1).

Alectona sp. 1 was collected in the Flemish Cap, off Newfoundland $\left(48^{\circ} 00.0031^{\prime} \mathrm{N}, 44^{\circ} 45.0644^{\prime} \mathrm{W}\right)$ at a depth of $1554 \mathrm{~m}$ (NEREIDA 0509 campaign, field\# DR10-056) (GeneBank accession COI MH256567; 18S MH256569).

Table 1. Localities of sponge specimens, museum voucher numbers, GB and ENA accession numbers used in this study.

\begin{tabular}{lccc}
\hline Thoosa Species & Locality & $\begin{array}{c}\text { Collection accession } \\
\text { number }\end{array}$ & $\begin{array}{c}\text { GenBank accession number } \\
\text { (CO1/ 18S/28S) }\end{array}$ \\
\hline $\begin{array}{l}\text { T. } \text { calpulli Carballo } \\
\text { et al. } 2004\end{array}$ & $\begin{array}{c}\text { Isabel Island Mexico, } 21^{\circ} 52^{\prime} 30^{\prime \prime} \mathrm{N}, \\
105^{\circ} 54^{\prime} 54^{\prime \prime} \mathrm{W}, 2 \mathrm{~m} \text { depth, } 21 \mathrm{Jul} / 2005\end{array}$ & LEB-ICML-UNAM-1332 & KU559625 -6/ MH236103 \\
$\begin{array}{l}\text { T. } \text { mismalolli Carballo } \\
\text { et al. } 2004\end{array}$ & $\begin{array}{c}\text { Isabel Island Mexico, } 21^{\circ} 52^{\prime} 30^{\prime \prime} \mathrm{N}, \\
105^{\circ} 54^{\prime} 54^{\prime \prime} \mathrm{W}, 2 \mathrm{~m} \text { depth, } 21 \mathrm{Jul} / 2005\end{array}$ & LEB-ICML-UNAM-1050 & KU559627 -8/ MH236102 \\
$\begin{array}{l}\text { T. purpurea } \text { Cruz-Barraza } \\
\text { et al. } 2011\end{array}$ & $\begin{array}{c}\text { Revillagigedo Island, } 18^{\circ} 44^{\prime} 10^{\prime \prime} \mathrm{N}, \\
110^{\circ} 57^{\prime} 37^{\prime \prime} \mathrm{W}, 5 \mathrm{~m} \text { depth, } 6 \text { May } 2008\end{array}$ & LEB-ICML-UNAM-1674 & $\begin{array}{c}\text { MH233578/ MH238470/ } \\
\text { MH233579 }\end{array}$ \\
\hline
\end{tabular}


Alectona sp. 2 was collected in deep-sea in the Mozambique Channel, Banc du Geyser (station DW4790: $12^{\circ} 22^{\prime} \mathrm{S}$, $\left.46^{\circ} 25^{\prime} \mathrm{E}\right)$, at a depth of 360-375 m (MNHN-BIOMAGLO 2017 campaign) (GeneBank accession COI MH256568). Alectona sp. 2 has large acanthoxeas similar to the ones in Alectona species but it also has centrotylote thin oxeas identical to the ones in Delectona so we are unsure of the genus identification at this point.

All samples were fixed in $96 \%$ ethanol and stored at room temperature before DNA extraction.

Total genomic DNA of Thoosa specimens was extracted using standard proteinase $\mathrm{K}$ digestion following the protocol from Aljanabi and Martínez (1997), but also the methodology described by Soler-Jiménez, García-Gasca, and Fajer-Ávila (2012). Specimens for which these protocols failed were subjected to an extraction using a SV Promega kit (Promega) following the manufacturer's instructions. The DNA of Alectona spp. were extracted using a DNeasy Blood and Tissue kit (Qiagen).

Partial sequences of the mitochondrial cytochrome oxidase subunit 1 gene (CO1), and ribosomal 18S rRNA and 28S rRNA were amplified. For amplification of the Thoosa CO1 fragment (659 bp), we used the degenerated primers of Folmer, Black, Hoeh, Lutz, and Vrijenhoek (1994) proposed by Meyer, Geller, and Paulay (2005): dgLCO1490 (5'-GGTCAACAAATCATAAAGAYATYGG-3) and dgHCO12198 (5'-TAAACTTCAGGGTGACCAAARAAYCA-3). The Alectona spp. CO1 fragment (659 bp) was obtained using the standard primers LCO1490 and HCO2198 (Folmer et al., 1994). The Thoosa $18 \mathrm{~S}$ rRNA gene was amplified using primers SP18aF (5-CCT GCC AGT AGT CAT ATG CTT-3) and SP18gR (5-CCT GCC AGT AGT CAT ATG CTT-3) (Redmond et al., 2013). The Alectona sp. 1, the $18 \mathrm{~S}$ rRNA gene was amplified in two parts with two sets of primers (4FB/1806R and S30/5FR), as described in Cárdenas et al. (2013). The D2 domain of the 28S rRNA gene was amplified with universal primers $\mathrm{C} 2$ (5-GAAAAGAACTTTGRARAGAGAGT-3) and D2 (5-TCCGTGTTT CAAGACGGG-3) (Chombard et al., 1998). In most cases each amplification was carried out in 11.5 $\mu \mathrm{L}$ volume reaction containing: $7.23 \mu \mathrm{L}$ of distilled $\mathrm{H}_{2} \mathrm{O}$ (sterile MilliQ), $0.75 \mu \mathrm{L} \mathrm{MgCl}_{2}, 2.5$ PCR buffer $5 \times$, $0.66 \mu \mathrm{L}$ dNTPs, $0.2 \mu \mathrm{L}$ primer F, $0.2 \mu \mathrm{L}$ of Primer R, 0.1 $\mu \mathrm{L}$ of Taq DNA polymerase (Promega), and $1 \mu \mathrm{L}$ of a $1 / 100$ dilution of the DNA extracts. Other reactions were made in $12.5 \mu \mathrm{L}$, as described in Cruz-Barraza, Vega, and Carballo (2014). Thermal cycling conditions were: an initial denaturation for $5 \mathrm{~min}$ at $94^{\circ} \mathrm{C}$, followed by $35-40$ cycles of $1 \mathrm{~min}$ at $94^{\circ} \mathrm{C}, 1 \mathrm{~min}$ at $48.4-55^{\circ} \mathrm{C}, 1 \mathrm{~min}$ at $72^{\circ} \mathrm{C}$ and final extension of $5 \mathrm{~min}$ at $72^{\circ} \mathrm{C}$. The PCR reaction was visualized on a $2 \%$ agarose gel, using TAE $1 \times$ as electrophoresis buffer for $25 \mathrm{~min}$ at $90 \mathrm{~V}$. The final products were purified with the Wizard SV Gel and PCR Clean-Up System (Promega) and sequencing was performed at Macrogen Inc. (Seoul, Korea).

Sequences were assembled using Geneious 5.6.4 software (Kearse et al., 2012) and CodonCode Aligner 2.0.1 (CodonCode Corporation). BLAST (NCBI/Blast) searches were used to verify the identity of sequences. For CO1 and 18S rRNA phylogenetic analyses we used the previously assembled datasets by Kelly and Cárdenas (2016), which include all Tetractinellida species sequenced to this date with outgroups from several other demosponge orders. For the 28S rRNA analyses we gathered published Tetractinellida sequence available in GenBank. Sequences of species of Cliona and Cliothosa (Clionaida order), were used as outgroup for this new $28 \mathrm{~S}$ alignment.

All sequences were aligned using MEGA 7 (Kumar, Stecher, \& Tamura, 2016) for each of the three loci, using the CLUSTALW alignment under the default gap opening-gap extension parameters (15.0-6.66). Maximum likelihood (ML) analyses were generated with RAxML 8.1.11 (Stamatakis, 2014) on the CIPRES science gateway v.3.3 portal (www.phylo.org) (Miller, Pfeiffer, \& Schwartz, 2010) using the GTRGAMMA model. In addition, a Bayesian inference (BI) analysis was performed with MrBayes 3.2.2 (Ronquist et al., 2012) using the $\mathrm{GTR}+\mathrm{I}+\mathrm{G}$ model of sequence evolution as obtained with jModelTest 2.1.7 (Darriba, Taboada, Doallo, \& Posada, 2012). The program was run with four Markov chains each 5,000,000-generations long, which were sampled every 200 th trees and a burn-in of $25 \%$. Posterior probabilities were computed from the remaining trees. Convergence was evaluated by viewing the log files in Tracer v1.5 (Rambaut \& Drummond, 2007), all parameters had effective sample sizes (ESS) $>300$.

\section{Results}

Two Alectona CO1 (sp.1 and sp.2) and one Thoosa purpurea $\mathrm{CO} 1$ sequence was obtained. The CO1 alignment (1216 bp) included 146 sequences, 698 sites were conservative and 518 were variable, of which 408 were parsimony informative. Alectona sp. 1 and three Thoosa species of the 18S rRNA sequences were obtained. The $18 \mathrm{~S}$ alignment (1741 bp) included 96 sequences, 1378 sites were constant and 328 were variable, of which 224 were parsimony informative. As for the 28S rRNA (D2) marker, only one sequence of Thoosa purpurea was obtained. The $28 \mathrm{~S}$ alignment (509 bp) included 36 sequences, 137 sites were constant and 347 were variable, of which 278 were parsimony informative.

Phylogenetic reconstructions of the three molecular markers (CO1, 18S, and 28S) were mostly congruent in both $\mathrm{ML}$ and $\mathrm{BI}$ analysis. The topologies obtained by ML analyses are presented, indicating for each node the support found by the different methods, bootstrap 


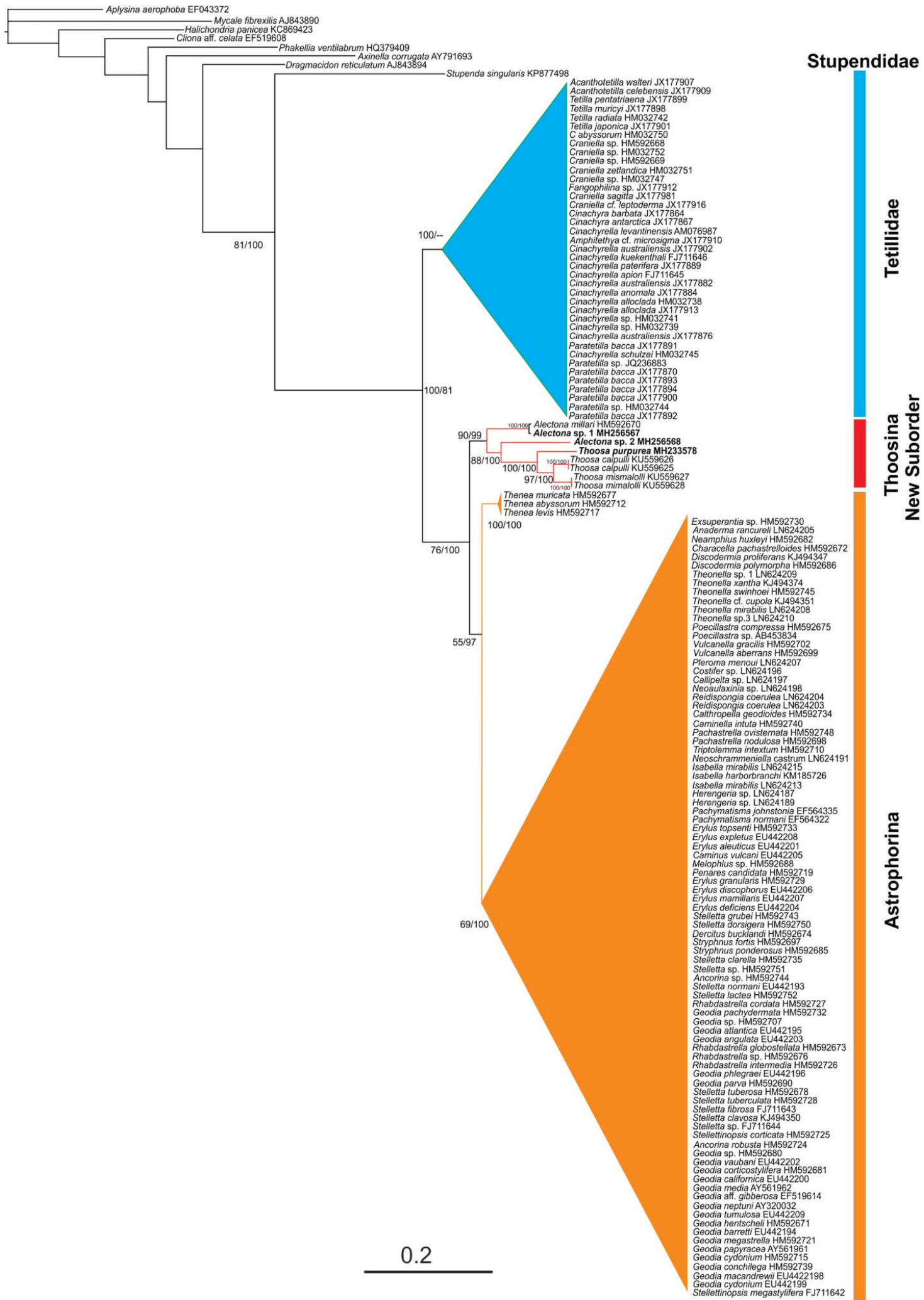

Fig. 1. Phylogenetic reconstruction of cytochrome c oxidase subunit (CO1) mitochondrial marker. The maximum likelihood (ML) topology (presented) was obtained by RAxML. The number at each node represents the ML bootstrap supports (100 bootstrap replicates) and Bayesian posterior probabilities (\%), only bootstrap supports above 50 are shown. GenBank accession numbers are given after each taxa name. New Thoosidae sequences are in bold. 


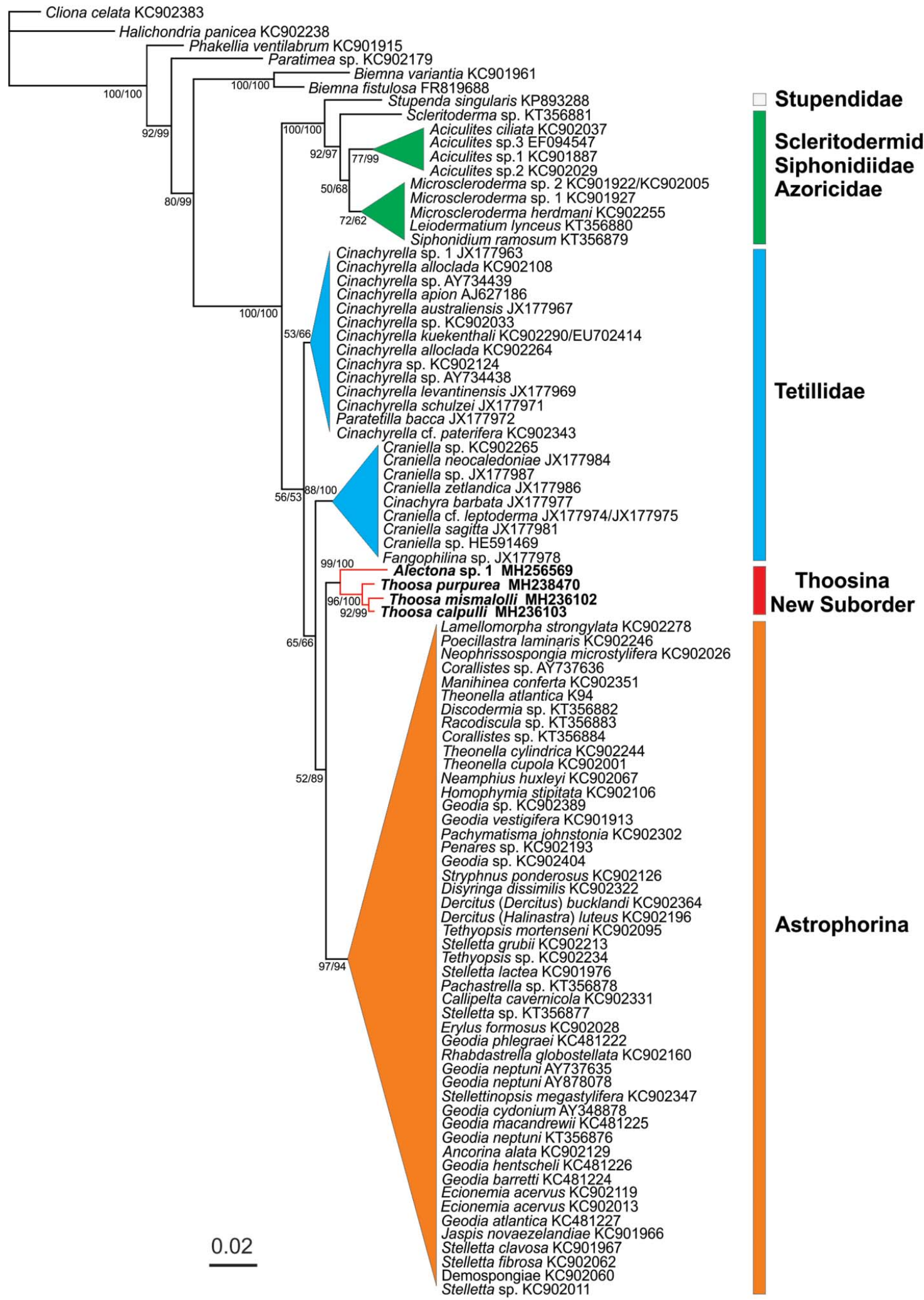

Fig. 2. Phylogenetic reconstruction of $18 \mathrm{~S}$ rRNA nuclear-ribosomal marker. The maximum likelihood (ML) topology (presented) was obtained by RAxML. The number at each node represents the ML bootstrap supports (100 bootstrap replicates) and Bayesian posterior probabilities (\%), only bootstrap supports above 50 are shown. GenBank accession numbers are given after each taxa name. New Thoosidae sequences are in bold. 


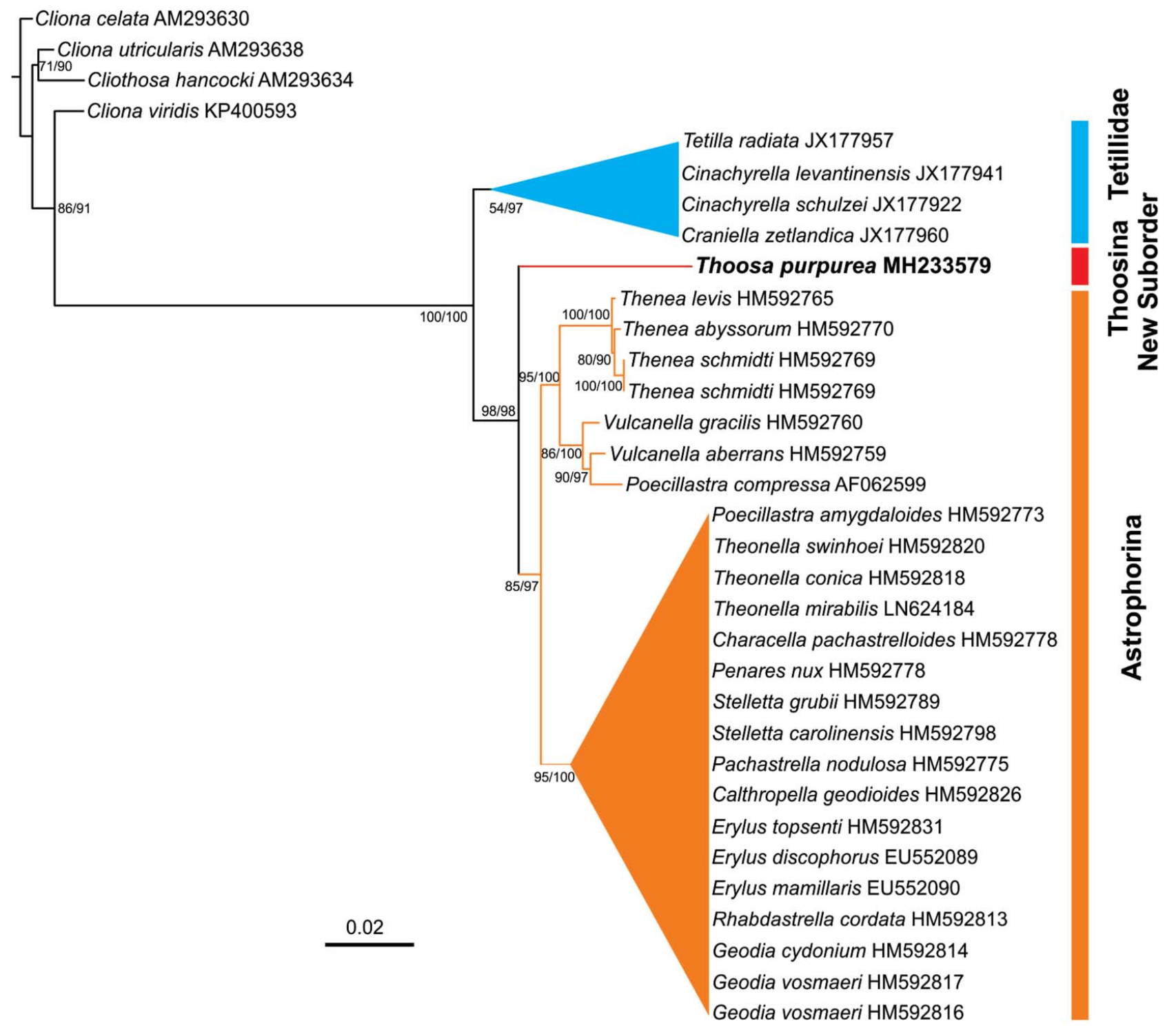

Fig. 3. Phylogenetic reconstruction $28 \mathrm{~S}$ rRNAgene fragment ' $\mathrm{D} 2$ ' marker. The maximum likelihood (ML) topology (presented), was obtained by RAxML. The number at each node represents the ML bootstrap supports (100 bootstrap replicates) and Bayesian posterior probabilities (\%), only bootstrap supports above 50 are shown. GenBank accession numbers are given after each taxa name.

proportion followed by posterior probabilities (BP/PP) (Figs 1, 2, 3). Both CO1 and 18S confirmed a well-supported grouping of Thoosa and Alectona. Specifically, CO1 topology showed that Alectona sp.2 was sister to all Thoosa spp. but in a separate clade than the other Alectona spp., which makes Alectona paraphyletic. All three markers agreed concerning the phylogenetic relationships of the Thoosa + Alectona clade. The three topologies suggested that the Thoosidae arose earlier than the Astrophorina (BP/PP: $\mathrm{CO} 1=76 / 100,18 \mathrm{~S}=$ $52 / 89,28 \mathrm{~S}=98 / 98)$. With both markers CO1 and $18 \mathrm{~S}$, Thoosa was monophyletic.

In general, the phylogenetic relationships obtained between Tetractinellida groups were congruent with previous molecular hypotheses (Cárdenas et al., 2011; Kelly \&
Cárdenas, 2016; Redmond et al., 2013; Schuster et al., 2015). The family Stupendidae was separated from the Tetillidae and Astrophorina clades (CO1), but closely related with the Scleritodermidae, Siphonidiidae, and Azoricidae (represented in 18S rRNAtree). The family Tetillidae was recovered as a monophyletic clade in $\mathrm{CO} 1$ and $28 \mathrm{~S}$ rRNA trees, but split in two clades in the 18S tree: the Craniella/Antarctotetilla/Cinachyra/Fangophilina clade formed a sister group to the Thoosidae+Astrophorina clade.

We now feel that we have enough evidence, based on the morphological and molecular data presented in this study, to say that the Thoosidae represents a unique demosponge clade for which we propose to create a new suborder of Tetractinellida. 


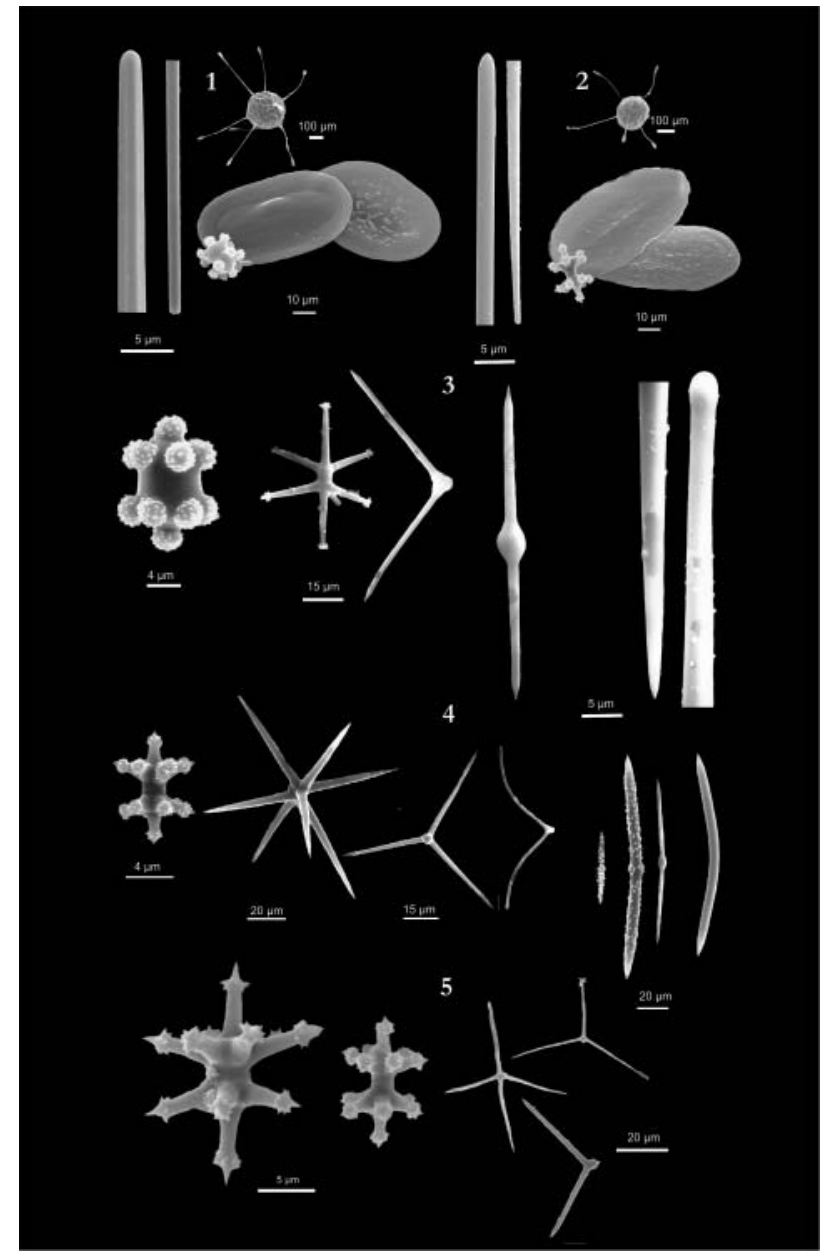

Fig. 4. SEM spicular elements of hoplitomella larva and adults of the three Mexican species of Thoosa. (1) Hoplitomella larva of $T$. mismalolli. Style, amphiaster, and view of the inner (right) and outer (left) surface of monaxonic disc. (2) Hoplitomella larva of T. calpulli. Style, amphiaster, and view of the inner (right) and outer (left) surface of monaxonic disc of T. calpulli. (3) Spicular elements of T. mismalolli; (left to right) Nodulose amphiaster, different forms of oxyasters, centrotylote oxeas, and head and tip of subtylostyles. (4) Spicular elements of T. calpulli; (left to right) Amphiaster, different forms of oxyasters and smooth and spined centrotylote oxea. (5) Spicules of T. purpurea; (left to right) Amphiasters and oxyasters bi- tri- tetra-radiate.

\section{Thoosina new suborder}

Definition. Excavating astrophorid sponges with planktonic armoured larvae (named 'hoplitomella'). Megascleres includes monactinal (styles and subtylostyles) or diactinal (acanthoxeas and acanthostrongyles) spicules. These spicules change or disappear in adult stages. Microscleres in adult stages are amphiasters, oxyasters, pseudosterrasters, spined triactines, and toxas. Monaxonic (Thoosa) and tetraxonic (Alectona) discs are present only in planktonic stages. Pits produced by species of this
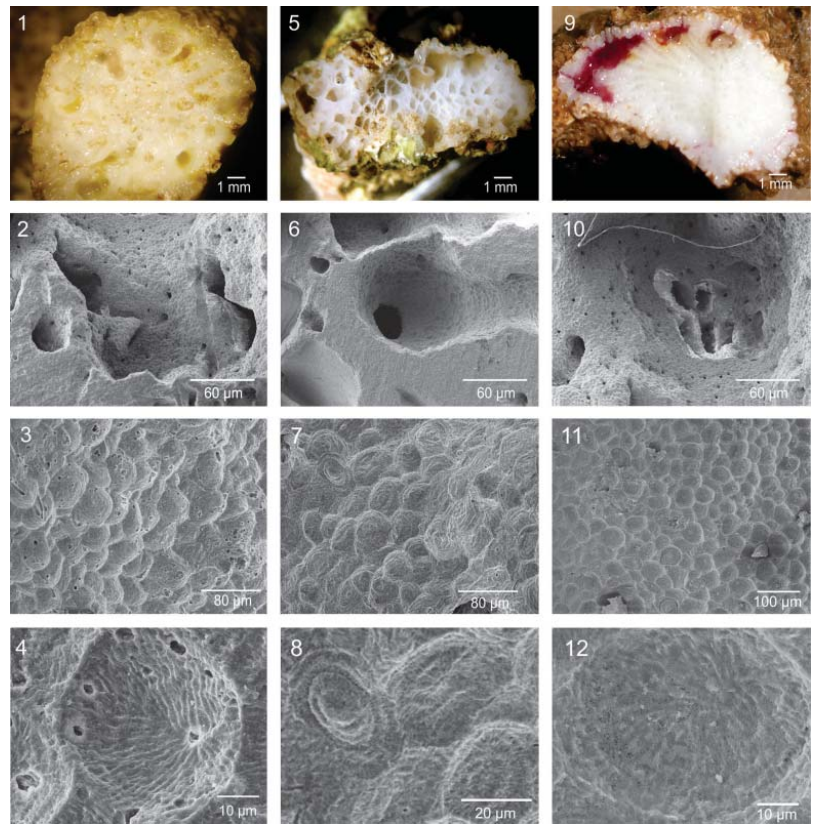

Fig. 5. Excavating pattern of Thoosa spp. in a cross-section fragment of the corals of the genus Pocillopora. (1-4) T. mismalolli (5-8) T. calpulli. (9-12) T. purpurea. In the first-row, cross-section view of a network of the excavating pattern. In the second row, details of a chamber to SEM where the pitting pattern is visible. In the third row, detail of the scars where chips were removed by the sponge (SEM). Last row, detail of a scar where there are clearly visible unusual micro-ornamentations with deep concentric etching marks with a characteristic radial pattern that overlaps the concentric (SEM).

group have unusual micro-ornamentations with deep concentric etching marks with a characteristic radial pattern that overlaps the concentric bands (Fig. 5).

Remarks. The new suborder contains the family Thoosidae Cockerell, 1925 with three genera: Thoosa Hancock, 1849, Alectona Carter, 1879, and Delectona de Laubenfels, 1936 (to be confirmed when molecular data are available). This family represents 29 valid species (Van Soest et al., 2017).

Thoosa is the most diverse genus with 16 species. The type species is Thoosa cactoides Hancock, 1849, found in a shell of Meleagrina margaritifera (Linnaeus, 1758) in the northern Indian Ocean, syntype is in the Hancock Museum, Newcastle, UK (4.17.05-06). Alectona Carter, 1879 , with 10 species is the second most diverse genus. The type species is Alectona millari Carter, 1879. Delectona Laubenfels, 1936 has four species. This genus was erected by Laubenfels (1936) for the type species Delectona higgini (Carter, 1879) from the Indian Ocean. All the species known in the suborder Thoosina are excavators of corals, mollusc shells, and other carbonate substrates. 


\section{Discussion}

The taxonomic status of the genera Alectona and Thoosa has been controversial (Alander, 1942; Topsent, 1891, 1928). These genera have no sign of radial architecture and have acquired an ovoviviparous mode of reproduction, which occurs through a larval type unique in the Porifera, which present spicules absent in adult stages (Fig. 4). Precisely, the presence of tetraxonic discs (discotriaenes) in the larvae of Alectona suggested its reallocation into the order Astrophorida (Vacelet, 1999). Subsequently, molecular studies corroborated the taxonomic affinities of Alectona millari with the astrophorins (Borchiellini et al., 2004; Cárdenas et al., 2011).

Due to similar pit structures, reproductive, and larval traits to Alectona, Thoosa was suggested to be included in the astrophorins as well (Bautista-Guerrero et al., 2010; Borchiellini et al., 2004; Vacelet, 1999), but this had never been supported by molecular data.

The molecular results obtained in this work showed congruence with the morphological peculiarities. Thus, the molecular phylogenetic trees using three independent loci confirm that Thoosa and Alectona are closely related, because the sequences are clustered in a monophyletic clade confirming the validity of the family Thoosidae, suggested by previous authors (Alander, 1942; Vacelet, 1999) and officially resurrected by Cárdenas et al. (2011) (Figs 1, 2, 3). Most importantly, the bootstrap and branches length shown in the molecular trees clearly separated Thoosidae (Thoosa and Alectona) from the rest of the families showing that it diverged after the Tetillidae and before the rest of the astrophorines.

Indeed, several morphological features shared by Alectona and Thoosa show they are quite different from the rest of the tetractinellids. The larvae of Alectona and Thoosa have spicules that are absent in adult stages (Bautista-Guerrero et al., 2010, 2016; Topsent, 1904; Vacelet, 1999) (Fig. 4). This is considered an ancient adult character because it is only observed during the embryogenesis and larval stages. Most importantly, the planktonic discs are homologous structures within Thoosidae: monaxonics in Thoosa lacking the short rhabdome (erroneously called discotriaenes by Bautista-Guerrero et al., 2010), and tetraxonics in Alectona (Bautista-Guerrero et al., 2016; Topsent, 1891; Vacelet, 1999). The discotriaenes are also found in all Theonellidae genera but one (Manihinea), but the monaxonic discs are so far exclusive of Thoosa larvae. The tetraxon megasclere and aster-type microsclere are considered morphological synapomorphies for Tetractinellida (Cárdenas et al., 2011). Aster-type microscleres are observed in Thoosa and Alectona, but the tetraxon feature is lacking in Thoosa (adults and larvae) while it is present in Alectona (larvae).
Interestingly the pits produced by Alectona during the excavating processes have unusual micro-ornamentations with deep concentric etching marks (Calcinai et al., 2004) which also occurred in Mexican Thoosa species (Fig. 5), all of them very different of those of other boring species (Calcinai, Arillo, Cerrano, \& Bavestrello, 2003).

Our study suggests that embryological and larval features must be considered to infer phylogenetic relationships in the Demospongiae.

\section{Acknowledgements}

J.L. Carballo, J.A. Cruz-Barraza and E. Bautista-Guerrero are grateful to the following sources of funding: CONACYT SEP CB-2015-01 (254806), PAPIIT-IA201614-2, and PRODEP-239013. We also thank PROZONA AC for their logistic support in some field sampling. We also thank María Berenit Mendoza from the UNAM, for some of the SEM images used in this paper. P. Cárdenas received support from the European Union's Horizon 2020 research and innovation programme through the SponGES project (grant agreement No. 679849). We would also like to acknowledge the staff involved in the NEREIDA project of IEO (Spanish Institute of Oceanography) CEFAS and DFO for providing specimens obtained during the NEREIDA surveys carried out on board the Spanish RV Miguel Oliver. Funding was received from the International Governance Strategy (IGS) fund of the Department of Fisheries and Oceans Canada Project 'Marine Biological Diversity Beyond Areas of National Jurisdiction (BBNJ): 3-Tiers of Diversity (GenesSpecies-Communities)' to E. Kenchington.

\section{Disclosure statement}

No potential conflict of interest was reported by the authors.

\section{Funding}

Consejo Nacional de Ciencia y Tecnología [grant number 254806]; PAPIIT [grant number-IA201614-2]; SponGES [grant number 679849]; PRODEP [grant number 239013]; SponGES project [grant number 679849].

\section{References}

Alander, H. (1942). Sponges from the Swedish west-coast and adjacent waters (PhD thesis). Göteborg, Sweden: University of Lund.

Aljanabi, S. M., \& Martinez, I. (1997). Universal and rapid saltextraction of high quality genomic DNA for PCR-based techniques. Nucleic Acids Research, 25, 4692-4693.

Bautista-Guerrero, E., Carballo, J. L., \& Maldonado, M. (2010). Reproductive cycle of the coral-excavating sponge Thoosa 
mismalolli (Clionaidae) from Mexican Pacific coral reefs. Invertebrate Biology, 129, 285-296.

Bautista-Guerrero, E., Carballo, J. L., Aguilar-Camacho, J. M., \& Sifuentes-Romero, I. (2016). Molecular and morphological differentiation of sympatric larvae of coral excavating sponges of genus Thoosa. Zoomorphology, 135, 159165.

Borchiellini, C., Alivon, E., \& Vacelet, J. (2004). The systematic position of Alectona (Porifera, Demospongiae): A tetractinellid sponge. Bollettino dei Musei e Degli Istituti Biologici dell'Università di Genova, 68, 209-217.

Calcinai, B., Arillo, A., Cerrano, C., \& Bavestrello, G. (2003). Taxonomy-related differences in the excavating micro-patterns of boring sponges. Journal of the Marine Biological Association of the United Kingdom, 83, 37-39.

Calcinai, B., Bavestrello, G., \& Cerrano, C. (2004). Bioerosion micro-patterns as diagnostic characteristics in boring sponges. Bollettino dei Musei e Degli Istituti Biologici dell'Università di Genova, 68, 229-238.

Carballo, J. L., Cruz-Barraza, J. A., \& Gómez, P. (2004). Taxonomy and description of clionaid sponges (Hadromerida, Clionaidae) from the Pacific Ocean of Mexico. Zoological Journal of the Linnean Society, 141, 353-397.

Cárdenas, P., Xavier, J. R., Reveillaud, J., Schander, C., \& Rapp, H. T. (2011). Molecular phylogeny of the Astrophorida (Porifera, Demospongiae) reveals an unexpected high level of spicule homoplasy. Public Library of Science ONE, 6(4), e18318. doi:10.1371/journal.pone.0018318

Cárdenas, P., \& Rapp, H. T. (2012). A review of Norwegian streptaster-bearing Astrophorida (Porifera: Demospongiae: Tetractinellida), new records and a new species. Zootaxa, 3253, 1-53.

Cárdenas, P., Rapp, H. T., Klitgaard, A. B., Best, M., Thollesson, M., \& Tendal, O. S. (2013). Taxonomy, biogeography and DNA barcodes of Geodia species (Porifera, Demospongiae, Tetractinellida) in the Atlantic boreoarctic region. Zoological Journal of the Linnean Society, 169, 251-311.

Carter, H. J. (1879). Contributions to our knowledge of the Spongida. Annals and Magazine of Natural History, 5, 284-304, 343-360.

Chombard, C., Boury-Esnault, N., \& Tillier, S. (1998). Reassessment of homology of morphological characters in tetractinellid sponges based on molecular data. Systematic Biology, 47, 351-366.

Cockerell, T. D. A. (1925). The family Clionidae. Science, 62, 567.

Cruz-Barraza, J. A., Carballo, J. L., Bautista-Guerrero, E., \& Nava, H. (2011). New species of excavating sponges (Porifera: Demospongiae) on coral reefs from the Mexican Pacific Ocean. Journal of the Marine Biological Association of the United Kingdom, 91, 999-1013.

Cruz-Barraza, J. A., Vega, C., \& Carballo, J. L. (2014). Taxonomy of family Plakinidae (Porifera: Homoscleromorpha) from Eastern Pacific Coral Reefs: molecular systematics through cox1 and cob mtDNA data. Zoological Journal of the Linnean Society, 171, 254-276.

Darriba, D., Taboada, G. L., Doallo, R., \& Posada, D. (2012). jModelTest 2: More models, new heuristics and parallel computing. Nature Methods, 9, 772.

de Laubenfels, M. W. (1936). A discussion of the Sponge Fauna of the Dry Tortugas in particular and the West Indies in general, with material for a revision of the families and orders of the Porifera. Papers from Tortugas Laboratory, 30, 1-225.

de Laubenfels, M. W. (1953). Sponges from the Gulf of Mexico. Bulletin of Marine Science of the Gulf and Caribbean, 2, 511-577.
Erpenbeck, D., Duran, S., Rützler, K., Paul, V., Hooper, J. N. A., \& Wörheide, G. (2007). Towards a DNA taxonomy of Caribbean demosponges: A gene tree reconstructed from partial mitochondrial $\mathrm{CO} 1$ gene sequences supports previous rDNA phylogenies and provides a new perspective on the systematics of Demospongiae. Journal of the Marine Biological Association of the United Kingdom, 87, 1563-1570.

Folmer, O., Black, M., Hoeh, W., Lutz, R., \& Vrijenhoek, R. (1994). DNA primers for amplification of mitochondrial cytochrome c oxidase subunit I from diverse metazoan invertebrates. Molecular Marine Biology and Biotechnology, 3, 294-299.

Hancock, A. (1849). On the excavating powers of certain Sponges belonging to the genus Cliona with descriptions of several new Species and an allied generic form. The Annals and Magazine of Natural History; Zoology, Botany, and Geology, 3, 321-348.

Kearse, M., Moir, R., Wilson, A., Stones-Havas, S., Cheung, M., Sturrock, S., ... Drummond, A. (2012). Geneious basic: An integrated and extendable desktop software platform for the organization and analysis of sequence data. Bioinformatics, $28,1647-1649$.

Kelly, M., \& Cárdenas, P. (2016). An unprecedented new genus and family of Tetractinellida (Porifera, Demospongiae) from New Zealand's Colville Ridge, with a new type of mitochondrial group I intron. Zoological Journal of the Linnean Society, 177, 335-352.

Kumar, S., Stecher, G., \& Tamura, K. (2016) MEGA7: Molecular evolutionary genetics analysis version 7.0 for bigger datasets. Molecular Biology and Evolution, 33, 1870-1874. doi:10.1093/molbev/msw054

Lavrov, D. V., Wang, X., \& Kelly, M. (2008). Reconstructing ordinal relationships in the Demospongiae using mitochondrial genomic data. Molecular Phylogenetics and Evolution, 49, 111-124.

Meyer, C. J., Geller, J. B., \& Paulay, G. (2005). Fine scale endemism on coral reefs: Archipelagic differentiation in turbinid gastropods. Evolution, 59, 113-125.

Miller, M. A., Pfeiffer, W., \& Schwartz, T. (2010). Creating the CIPRES Science Gateway for inference of large phylogenetic trees. Proceedings of the Gateway Computing Environments Workshop (GCE) (pp. 1-8), 14 Nov. 2010. New Orleans, LA.

Morrow, C. C., Redmond, N. E., Picton, B. E., Thacker, R. W. Collins, A. G., Maggs, C. A., ... Allcock, A. L. (2013). Molecular phylogenies support homoplasy of multiple morphological characters used in the taxonomy of Heteroscleromorpha (Porifera: Demospongiae). Integrative and Comparative Biology, 53, 428-446.

Morrow, C., \& Cárdenas, P. (2015). Proposal for a revised classification of the Demospongiae (Porifera). Frontiers in Zoology, 12, 7. doi:10.1186/s12983-015-0099-8

Nichols, S. A. (2005). An evaluation of support for order-level monophyly and interrelationships within the class Demospongiae using partial data from the large subunit rDNA and cytochrome oxidase subunit I. Molecular Phylogenetics and Evolution, 34, 81-96.

Rambaut, A., \& Drummond, A. J. (2007). Tracer v1.4: MCMC trace analyses tool. Retrieved from http://tree.bio.ed.ac.uk/ software/tracer/ (accessed 13 March 2018).

Redmond, N. E., Morrow, C. C., Thacker, R. W., Diaz, M. C., Boury-Esnault, N., Cárdenas, P., \& Collins, A. G. (2013). Phylogeny and systematics of Demospongiae in light of new small-subunit Ribosomal DNA (18S) sequences. Integrative and Comparative Biology, 53, 388-415. Retrieved from https://doi.org/10.1093/icb/ict078 
Redmond, N. E., Raleigh, J., Soest, R. W. van., Kelly, M., Travers, S. A., Bradshaw, B., \& McCormack, G. P. (2011). Phylogenetic relationships of the marine Haplosclerida (Phylum Porifera) employing ribosomal (28S rRNA) and mitochondrial (cox1, nad1) gene sequence data. Public Library of Science One, 6, e24344. doi:10.1371/journal. pone. 0024344

Ronquist, F., Teslenko, M., van der Mark, P., Ayres, D. L., Darling, A., Höhna, S., \& Huelsenbeck, J. P. (2012). MrBayes 3.2: Efficient Bayesian phylogenetic inference and model choice across a large model space. Systematic Biology, 61, 539-542.

Rosell, D. (1996). Systematics, biology and ecology of mediterranean excavating sponges (Ph.D. Thesis). Barcelona, Spain: University of Barcelona.

Rützler, K. (2002a). Family Clionaidae D'Orbigny, 1851. In J. N. A. Hooper \& R. W. M. Van Soest (Eds.), Systema Porifera: A guide to the classification of Sponges (pp. 173-185). New York: Kluwer Academic/Plenum Press.

Rützler, K. (2002b). Family Alectonidae Rosell, 1996. In J. N. A. Hooper \& R. W. M. Van Soest (Eds.), Systema Porifera: A guide to the classification of sponges (pp. 281-290). New York: Kluwer Academic/Plenum Press.

Rützler, K., \& Stone, S. M. (1986). Discovery and significance of Albany Hancock's microscope preparation of excavating sponges (Porifera: Hadromerida: Clionidae). Proceeding of the Biological Society of Washington, 99, 263-268.

Schuster, A., Erpenbeck, D., Pisera, A., Hooper, J. N. A., Bryce, M., Fromont, J., \& Wörheide, G. (2015). Deceptive desmas: Molecular phylogenetics suggests a new classification and un- covers convergent evolution of lithistid demosponges. Public Library of Science ONE, 10, e116038. doi:10.1371/ journal.pone.0116038

Soler-Jiménez, L. C., García-Gasca, A., \& Fajer-Ávila, E. J. (2012). A new species of Euryhaliotrematoides Plaisance \& Kritsky, 2004 (Monogenea: Dactylogyridae) from the gills of the spotted rose snapper Lutjanus guttatus (Steindachner) (Perciformes: Lutjanidae). Systematics Parasitology, 82, 113-119.

Stamatakis, A. (2014). RAxML version 8: A tool for phylogenetic analysis and post-analysis of large phylogenies. Bioinformatics, 30, 1312-1313.

Topsent, E. (1891). Deuxième contribution à l'étude des Clionides. Archives de Zoologie Expérimentale et Général, 9, 555-592.

Topsent, E. (1904). Spongiaires des Açores. Résultats des campagnes scientifiques accomplies par le Prince Albert I Monaco, 25, 1-280, 281-218.

Topsent, E. (1920). Caractères et affinités des Thoosa Hanc. et des Alectona Cart. Considérations sur leurs germes à armure. Bulletin de la Société Zoologique de France XLV, 15, 88-97.

Topsent, E. (1928). Spongiaires de l'Atlantique et de la Méditerranée provenant des croisières du Prince Albert ler de Monaco. Résultats des Campagnes Scientifiques Accomplies par le Prince Albert I. Monaco, 74, 1-376.

Vacelet, J. (1999). Planktonic armoured propagules of the excavating sponge Alectona (Porifera: Demospongiae) are larvae: Evidence from Alectona wallichii and A. mesatlantica sp. nov. Memoirs of the Queensland Museum, 44, 627642.

Van Soest, R. W. M., Boury-Esnault, N., Hooper, J. N. A., Rützler, K., de Voogd, N. J., Alvarez, B., ... Downey, R. (2017). World Porifera database. Retrieved from http:// www.marinespecies.org/porifera (accessed 13 March 2018).

Van Soest, R. W. M., Boury-Esnault, N., Vacelet, J., Dohrmann, D., Erpenbeck, N., Voogd, N., \& Hooper, J. N. A. (2012). Global diversity of sponges (Porifera). Public Library of Science ONE, 7, e35105. doi:10.1371/journal. pone. 0035105

Associate Editor: Ana Riesgo 